Prepared in cooperation with the U.S. Department of Agriculture Natural Resources Conservation Service, the Edwards Region Grazing Lands Conservation Initiative, the Texas State Soil and Water Conservation Board, the San Antonio River Authority, the Edwards Aquifer Authority, Texas Parks and Wildlife, the Guadalupe Blanco River Authority, and the San Antonio Water System

\title{
Effects of Brush Management on the Hydrologic Budget and Water Quality In and Adjacent to Honey Creek State Natural Area, Comal County, Texas, 2001-10
}

Woody vegetation, including ashe juniper (Juniperus ashei), has encroached on some areas in central Texas that were historically oak grassland savannah (Bray, 1904). Encroachment of woody vegetation is generally attributed to overgrazing and fire suppression (Bray, 1904; Van Auken, 2000). Removing the ashe juniper and allowing native grasses to reestablish in the area as a brush management conservation practice (hereinafter referred to as "brush management") might change the hydrology in the watershed (Thurow and Hester, 1997; Tennesen, 2008). These hydrologic changes might include changes to surfacewater runoff, evapotranspiration, or groundwater recharge.

The idea of hydrologic changes resulting from brush management generally is based on a simplified mass balance approach to the hydrologic cycle in which rainfall accounts for the water coming into the system and rainfall is distributed to surface-water runoff (streamflow), evapotranspiration (combination of evaporation and transpiration), or groundwater recharge (subsurface flow that contributes to the groundwater table or contributes to spring discharge downstream from the study area) (Zhang and others, 2002). If the amount of rainfall remains constant and the evapotranspiration rates change because of a change in vegetation cover, then the surface-water or groundwater components of the hydrologic budget will change.

The U.S. Geological Survey (USGS), in cooperation with Federal, State, and local partners, examined the hydrologic effects of brush management in two adjacent watersheds (figs. 1 and 2). Hydrologic data were collected in the watersheds for 3-4 years (pretreatment) depending on the type of data, after which brush management occurred on one watershed (treatment watershed) and the other was left in its original condition (reference watershed). Hydrologic data were collected in the study area for another 6 years (post-treatment). These hydrologic data included rainfall, streamflow (fig. 3), evapotranspiration (fig. 1), and water quality. Groundwater recharge was not directly measured, but potential groundwater recharge was calculated by using a simplified mass balance approach.

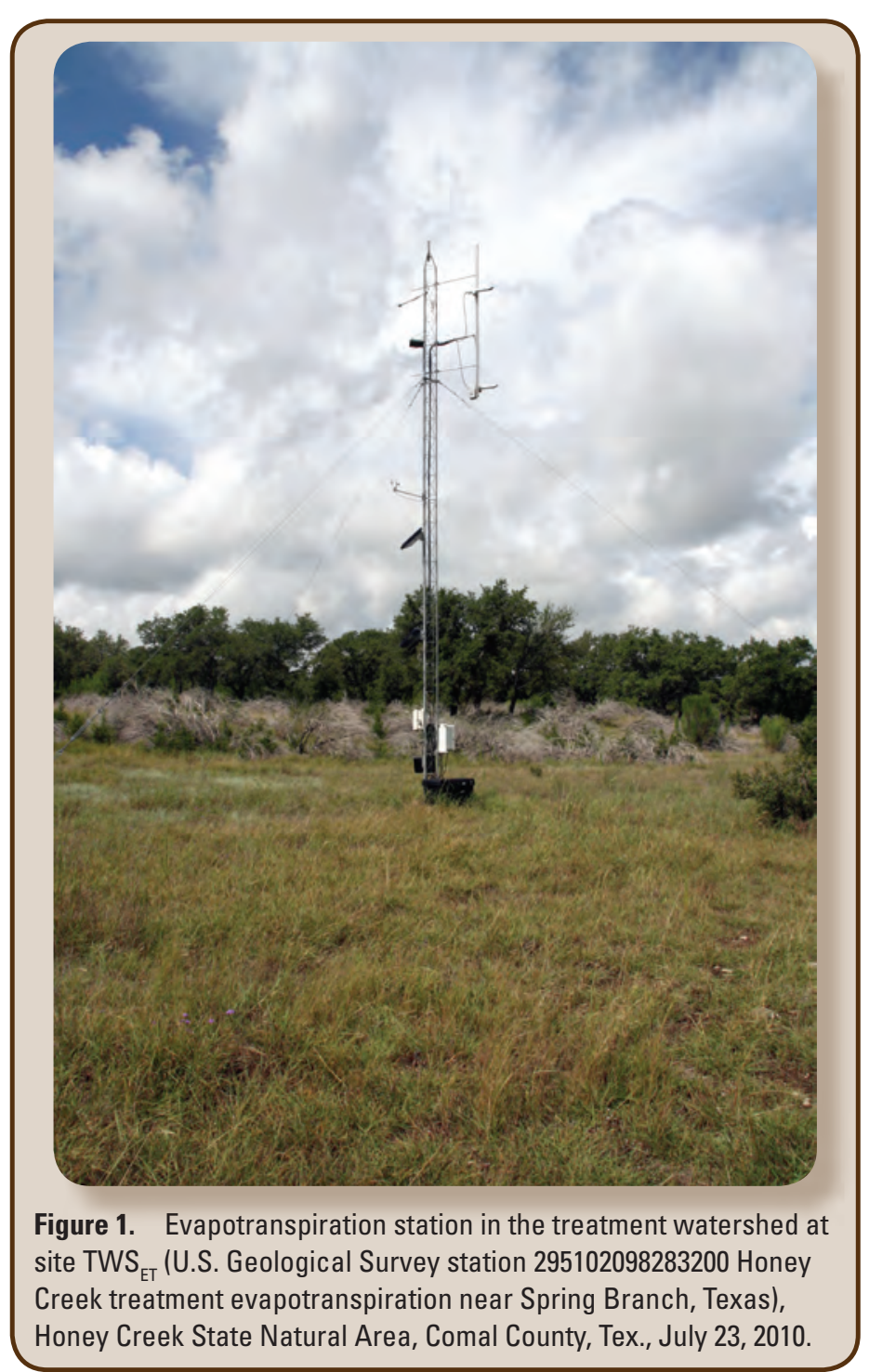




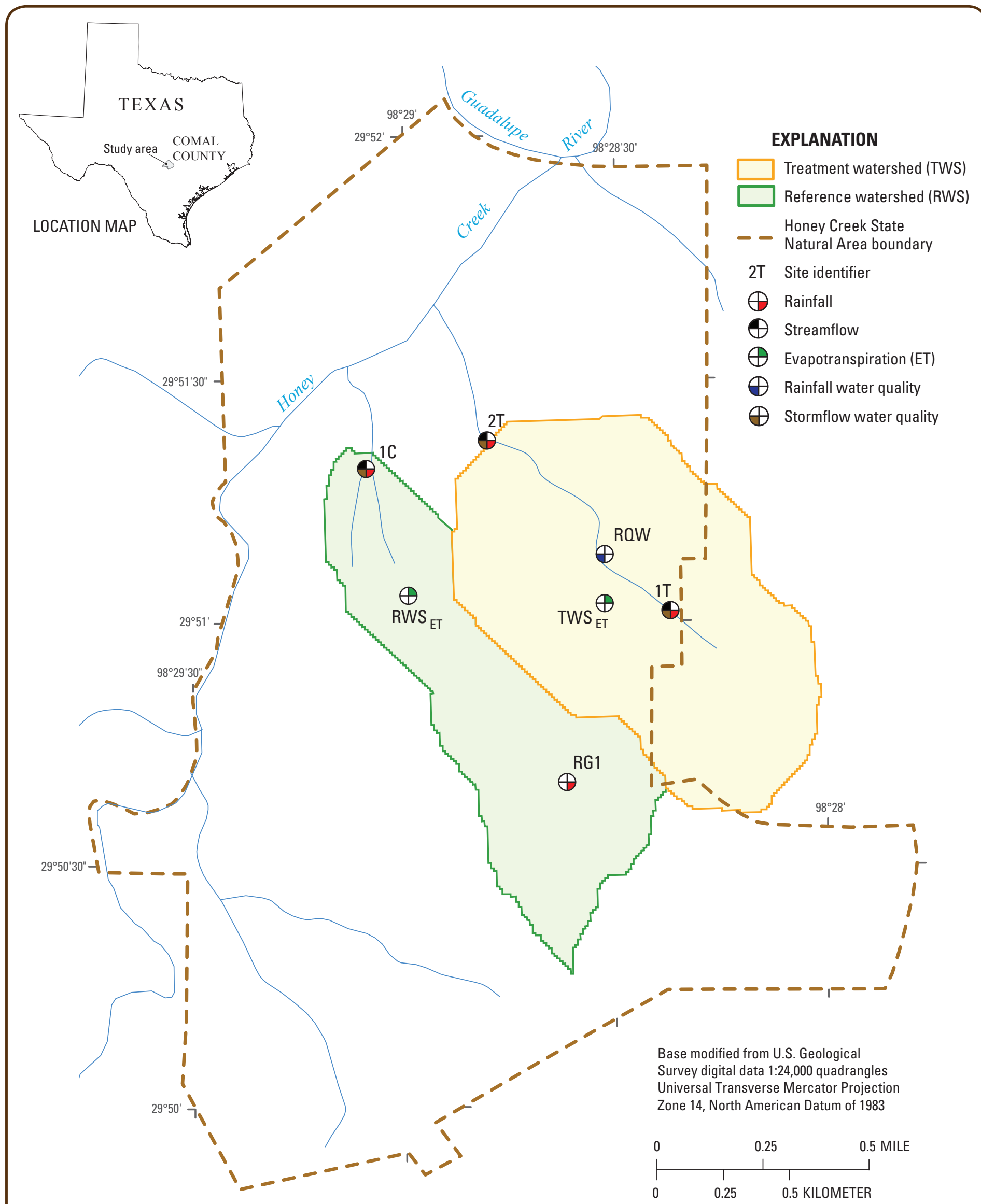

Figure 2. Locations of data-collection sites in the Honey Creek State Natural Area, Comal County, Texas. 


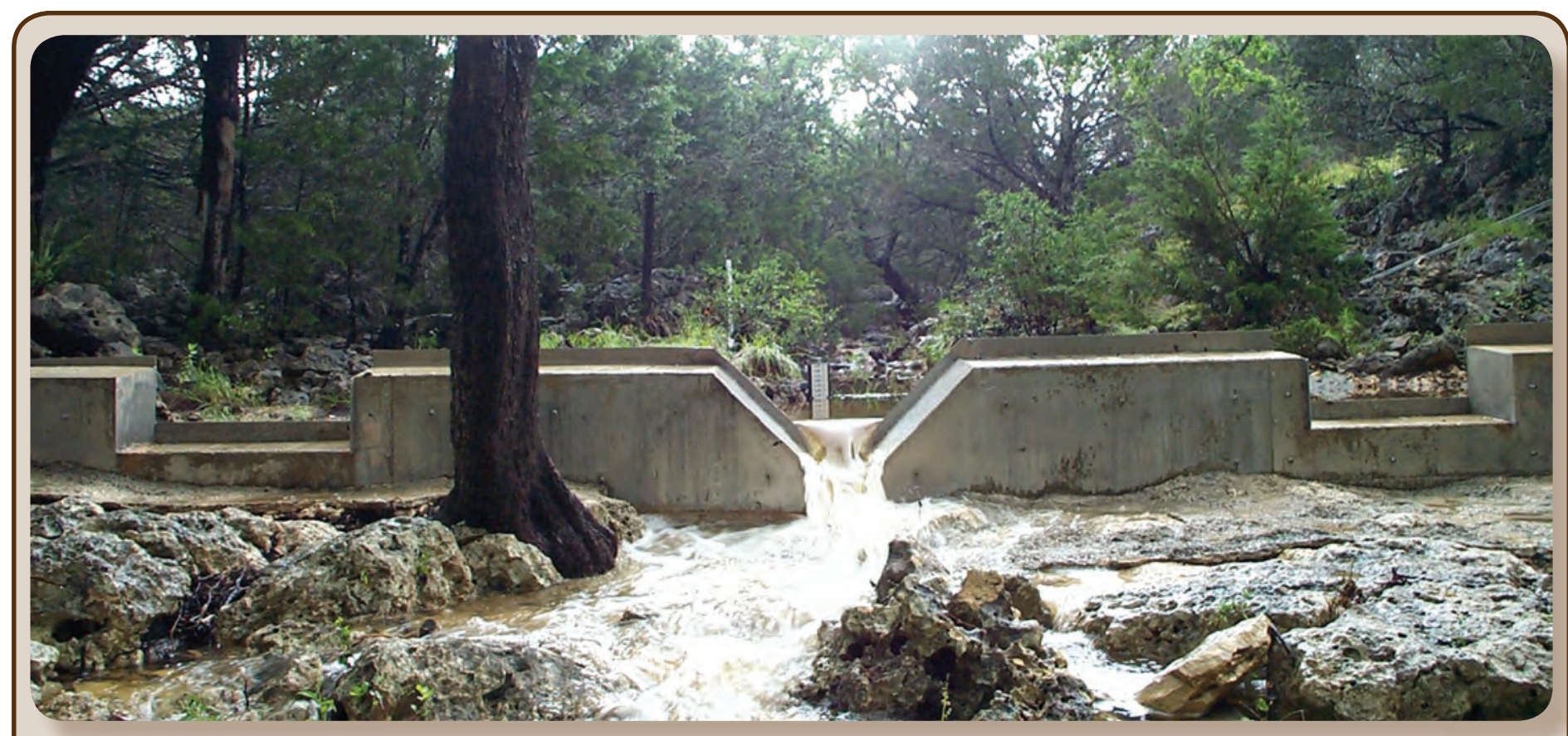

Figure 3. Streamflow-gaging stations were installed in the study area, such as this weir in the treatment watershed at site 2T (U.S. Geological Survey station 08167353 Unnamed tributary of Honey Creek site 2T near Spring Branch, Texas), Honey Creek State Natural Area, Comal County, Tex.

The following highlights of the study are summarized from the USGS Scientific Investigations Report (Banta and Slattery, 2011) on which this fact sheet is based:

- The streamflow to rainfall relation (expressed as event unit runoff to event rainfall relation) did not change between the watersheds during pre- and posttreatment periods.

- Daily evapotranspiration rates at the reference

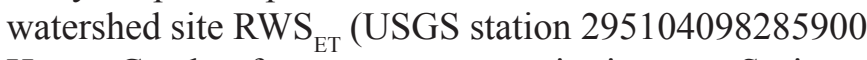
Honey Creek reference evapotranspiration near Spring Branch, Tex.; fig. 2) and the treatment watershed site TWS $_{\text {ET }}$ (USGS station 295102098283200 Honey Creek treatment evapotranspiration near Spring Branch, Tex.; fig. 2) exhibited a seasonal cycle during the pre- and post-treatment periods, with intraannual and interannual variability (fig. 4). Statistical analyses indicate that the mean difference in daily evapotranspiration rates between the two sites $\left(\mathrm{RWS}_{\mathrm{ET}}-\mathrm{TWS}_{\mathrm{ET}}\right.$ ) is greater during the post-treatment period than it was during the pre-treatment period.

- Average annual rainfall, streamflow, evapotranspiration, and potential groundwater-recharge conditions were incorporated into a hydrologic budget (expressed as a percentage of the average annual rainfall) for each watershed pre- and post-treatment to evaluate the effects of brush management. The percent average annual unit runoff in the reference watershed was similar to that in the treatment watershed during both the pre- and post-treatment periods. In contrast, the difference in percentages of average annual evapotranspiration and potential groundwater recharge during the post-treatment period were more appreciable between the reference and treatment watersheds than during the pre-treatment period.

- Graphical comparisons indicated that there were no notable differences in major ion or nutrient concentrations between samples collected at the reference watershed site 1C (USGS station 08167347 Unnamed tributary of Honey Creek site 1C near Spring Branch, Tex.; fig. 2) and the treatment watershed site 2T (USGS station 08167353 Unnamed tributary of Honey Creek site 2T near Spring Branch, Tex.; fig. 1) during pre- and post-treatment periods.

- The relation between suspended-sediment loads and streamflow calculated from samples collected from sites $1 \mathrm{C}$ (in the reference watershed) and $2 \mathrm{~T}$ (in the treatment watershed) did not exhibit a statistically significant difference during the pre-treatment period, whereas during the post-treatment period, the relation between suspended-sediment loads and streamflow did exhibit a statistically significant difference. The relations of suspended-sediment load to streamflow indicate that, for the same streamflow, the suspendedsediment loads calculated from site $2 \mathrm{~T}$ were generally less than the suspended-sediment loads calculated from site $1 \mathrm{C}$ during the post-treatment period. 

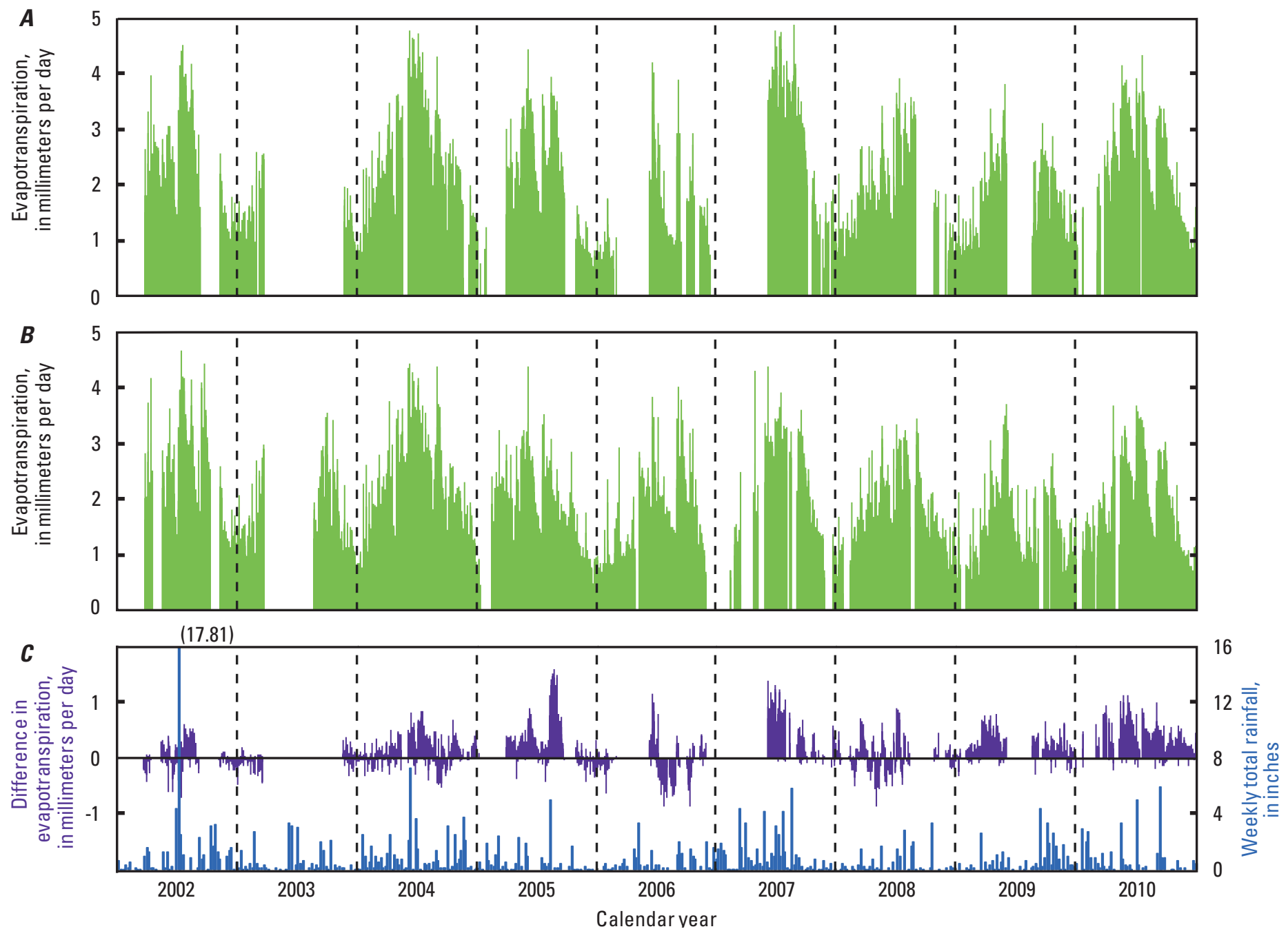

Figure 4. Daily evapotranspiration data at $A$, the reference watershed evapotranspiration site RWS $\mathrm{ET}_{\mathrm{ET}}$ (U.S. Geological Survey station 295104098285900 Honey Creek reference evapotranspiration near Spring Branch, Texas) and $B$, the treatment watershed evapotranspiration

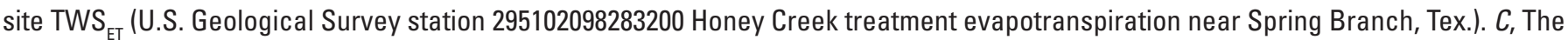
difference in evapotranspiration between the sites $\left(\mathrm{RWS}_{\mathrm{ET}}-\mathrm{TWS}_{\mathrm{ET}}\right)$, along with weekly total rainfall in the study area.

\section{Selected References}

Banta, J.R., and Slattery, R.N., 2011, Effects of brush management on the hydrologic budget and water quality in and adjacent to Honey Creek State Natural Area, Comal County, Texas, 2001-10: U.S. Geological Survey Scientific Investigations Report 2011-5226, 35 p. (Available online at http://pubs.usgs.gov/sir/2011/5226/.)

Bray, W., 1904, The timber of the Edwards Plateau of Texas; its relation to climate, water supply, and soil: U.S. Department of Agriculture, Bulletin No 49.

Tennesen, M., 2008, When juniper and woody plants invade, water may retreat: Science, v. 332, p. 1630-1631.

Thurow, T.L., and Hester, W.H., 1997, How an increase or reduction in juniper cover alters rangeland hydrology: Juniper Ecology and Management, 1997 Juniper Symposium, chap. 4, accessed March 9, 2011, at http://texnat.tamu.edu/library/ symposia/juniper-ecology-and-management/how-an-increaseor-reduction-in-juniper-cover-alters-rangeland-hydrology/.
Van Auken, O.W., 2000, Shrub invasions of North American semiarid grasslands: Annual Review of Ecology and Systematics, v. 31, p. 197-215.

Zhang, L., Walker, G.R., and Fleming, M., 2002, Surface water balance for recharge estimation: Collingwood, Australia, CSIRO Publishing, $20 \mathrm{p}$.

\section{-J. Ryan Banta and Richard N. Slattery}

For additional information, contact

Director, Texas Water Science Center U.S. Geological Survey

1505 Ferguson Lane

Austin, Texas 78754-4501

http://tx.usgs.gov/

Publishing support provided by

Lafayette Publishing Service Center 